\title{
An Assessment of the Impact of Industrial Development Centres (IDCS) On Generation of Employment by Small -Scale Businesses in Nigeria
}

\author{
Dende Gbolagade Adejumo \\ University of Ilorin, Nigeria \\ P.M.B. 1515 Ilorin, Nigeria \\ E-mail: gbolajumo@yahoo.com
}

Received: February 15, 2011

Accepted: May 28, 2011

doi:10.5539/jsd.v4n3p249

\begin{abstract}
The study assessed the impact of Industrial Development Centres (IDCs) on employment generation by small-scale businesses in Nigeria .The study was designed primarily to determine whether or not the generation of employment of small-scale businesses beneficiaries of the IDCs increased significantly after obtaining IDCs' services. The study indicated that the services offered by many (66.7\%) of the IDCs led to significant increase in employment generation by large number of beneficiary small- scale businesses at $1 \%$ level but at $5 \%$ level the services offered by many (66.7\%) IDCs did not lead to significant increase in employment generation by large number of small-scale businesses beneficiaries. The study also indicated that there were significant differences among the IDCs regarding changes in employment generated by their beneficiary small-scale businesses after receiving services.
\end{abstract}

Keywords: Small-Scale, Businesses, Employment, Generation, Beneficiaries

\section{Introduction}

The background to Federal Government active participation in the development of small-scale businesses was traceable to the advice of the United Nations to Nigerian Government in the early 1960's that 'if small-scale businesses are adequately assisted, they will provide a solid foundation for industrial development'. One of the measures put up regarding this approach was the establishment of Industrial Development Centres in Nigeria. Accordingly, the then Eastern Nigeria Ministry of Trade and 1ndustry established the first Industrial Development Centre (IDC) in Owerri in 1962.The military government took over the operation of IDC Owerri in 1970 and initiated the setting up of the other IDCs in other states of the Federation. As at 2010, there were 23 IDCs in the country. The taking over of the IDCs in Owerri and the setting up of the other IDCs were predicated on the expectation that they would make positive impacts on the growth and development of small-scale businesses in Nigeria. Specifically the IDCs are expected to make positive impact on the employment generation of beneficiary small-scale businesses among other things. The main functions of IDCs are as follows: (a)Technical appraisal of loan applications, (b) Provision of industrial extension services,(c) Training of entrepreneurs and their staff including management training,(d) Applied research into industries products involving design of products for SSBs and (e) Helping small - scale businesses to purchase and install machinery

The Federal Government has since 1960s spent a lot of money on the establishment and running of IDCs in the Federation. For example, the Federal Government has provided workshops, machines, offices and other amenities like motor vehicles. The Federal Government on the average spent more than N500,000 per quarter on the smallest IDC in the Federation .In 1997 alone, the Federal Government expended N39 million to strengthen three IDCs in the Federation and N81 million for the development of other IDCs. (Federal Ministry of Finance, 1997). IDCs were handed over to Small and Medium Enterprise Development Agency of Nigeria (SMEDAN) in 2009.

\section{Literature Review}

Development literature may not agree on a single definition of small and medium scale businesses (SMBs), but there is some high level of consensus on the importance of SMBs roles in economic growth and development. A survey of the available empirical evidence indicated that a general tendency for small-scale industries to be relatively more important in less developed countries (LDCs) including) Nigeria than developed ones. Sutcliffe (1971) states that there is enormous number of very small firms and a small number of very large firms but there is a lack of medium-sized factory industry which is common in more industrialized countries. Staley and Morse (1965) asserted that small-scale industrialized activities will flourish when locational factors are such as to encourage the spatial dispersion of decentralization of such activities, as for example is the case with factories 
processing dispersed raw materials or supplying local market with a final product that is expensive to transport. Staley and Morse (op cit, 1965) further asserted that differentiated products having low scale economies and serving small total markets are likely to be produced in large number of small -establishments. Anderson (1982) posited that available empirical evidence suggests that a significant part of growth of large-scale enterprises are rooted in the expansion of once small firms. Sutcliffe (1971) claimed that small-scale industries have several advantages. The advantages claimed for such industries include the following:They encourage entrepreneurship and economizing in its use(Schatz).They are more likely to utilize labour intensive technologies than large scale industries and are more effective creators of direct employment opportunities(Sutcliffe).They can usually be rapidly established and put into operation to produce quick returns (Bryce,1960). Their development can encourage the process of both inter and intra-regional industrialization. They can be located both in smaller urban centres and rural areas (Kilby,1971). Their development can permit the development of wide and economic and social-political objective

According to Schmitz (1982), the potential of small-scale enterprises is not always realized due to problems faced by indigenous enterprises which he classified as 'internal' constraints (relating to entrepreneurial competence) and 'external or environmental 'constraints

Realization of the advantages of small-scale industries has made many countries to adopt strategies and options for development of small-scale industries. The strategies and options adopted for development of small-scale industries could be grouped into two broad categories: employment-oriented and laissez-faire.

\subsection{Employment-oriented group:}

Countries in this group include India, Indonesia, Malaysia and Nigeria. Small-Scale enterprises in this group are usually accorded with support in financing, marketing, technical training, factory accommodation, etc free of charge or at subsidized costs (Akhauri, 1990). The government of India has provided some important inputs and supports for small- scale businesses over the past years. These include: The establishment of National Smallscale Industries Corporation (NSIC) for arranging machinery and other inputs on hire purchase; The establishment of Small Industries Extension Training Institute(SIET) for training extension officers and entrepreneurs; and the establishment of a network of Industrial Estates throughout the country by which sheds with necessary facilities were made available

Some of the important inputs and supports provided by the government of Indonesia over the past years include :The setting up of the Mini-industrial Estates (MIEs) designed to serve the Small-Industrial Enterprises by meeting their demands for raw materials and market promotion for their products; the development of programme for financial assistance to small-scale businesses; and the creation of clusters to promote and integrate assistance to small industrial enterprises in the same sector by buying raw materials for common stock and by supplying common equipment and facilities.

The inputs and supports provided for promotion and development of small- scale businesses by Malaysian government include: Provision of loans by public sector agencies such as the Majlis Amanah Rackyat(MARA) and Malaysian Industrial Development Finance Corporation (MIDC), etc; and establishment of institutions for development of entrepreneurship such as National Productivity Centre(NPC) and Industrial Training Institutes.

The Programmes which have been put forward by the Federal Government of Nigeria since early 1960's include: The creation of Industrial Development Centres(IDCs), Working For yourself/Entrepreneurship Development Programme WFYP/EDP, and National Economic and Reconstruction Fund(NERFUND) (Odetola, 2002)

\subsubsection{Laissez-faire Approach}

South Korea and Hong Kong have adopted this approach. Countries that have adopted this approach have specific reasons regarding the promotion of Small-Scale sector at a particular point in time. By and large, market forces of supply and demand and competition between enterprises are stronger forces affecting the development of small -Scale business in the countries adopting this approach. For examples: The strategy of South Korea as at 1990 was clearly one of selective promotion- with the exception of those favoured Small-Scale Businesses that had to pay market cost of finance and other services; In Korea, from 1961 to 1963, the government policies towards development of small-scale businesses were aimed at establishing bodies charged with the responsibilities of promoting small -businesses and the enactment of laws to support the effective functioning of such bodies. Whereas from 1966 to1967, the government reviewed, integrated and systematized its policy towards the small-business sector. To do this, some lines of actions were taken, some of which include: The formation of the committee on fina ncial assistance to small businesses to strive for co-operation among banking institutions for small industry financing; setting up of the council of small industry policy; and the use of foreign source of loans by small businesses to help them modernize their production facilities

\subsubsection{What Drives Small-Scale Businesses in Nigeria?}

In a study that comparatively assessed the individual impact of ten 'key factors' influencing business failure within the small and medium businesses sector between the United Kingdom (UK) and Nigeria, it was found that external factors such as poor economic conditions and inadequate infrastructure were the most crucial factors 
that influenced business failure in Nigeria(Ugwushi,2009). Omohezuaun and Inegbenebor(2009) asserted that the commonly adduced reasons for the inability of SMBs to meet the expectations of government in accelerating job creation, increase the production of goods and services, facilitate technology transfer, create more opportunities for entrepreneurs and in particular, increase the local content component of the giant multinational companies in Nigeria were lack of access to credit facilities. According to Isaac et al(2005), the reasons for lack of access credit facilities are: (i) SMBs are regarded by creditors and investors as high- risk borrowers because of insufficient assets and low capitalization, vulnerability to market fluctuations and high mortality rates; (ii) information asymmetry arising from SMBs' lack of accounting records, inadequate accounting statements or business plans makes it difficult for creditors and investors to access the creditworthiness of potential SMBs proposals; and (iii) high administrative/transaction costs of lending or investing small amounts do not make SMB financing a profitable business".

\section{Statement of Research problem}

Despite the long existence of the IDCs and the huge amount of money that has been expended on them, no study has been conducted to assess their impacts on generation of employment of beneficiary small-scale businesses. The specific objective of the study therefore, is the assessment of the impact of the IDCs on employment generation of beneficiary small-scale businesses.

\section{Research objective}

The study aims to assess the impact of IDCs on generation of employment of their beneficiary Small-Scale businesses.

\section{Research Setting: Twelve IDCs}

Twelve IDCs were chosen for this study. These were made up of three IDCs in each of the four zones in Nigeria: North Western, North Eastern, South Eastern, and South Western zones The IDCs in each zone included the biggest centre and two of the smaller centres in the zone.

\section{Research Methodology}

Based on the research objective, the following null hypotheses were formulated:

1) The employment generated by the IDCs beneficiary small -scale businesses did not increase significantly after obtaining services from IDCs, and

2) There were no significant changes in employment generated among the IDCs beneficiary small-scale businesses after obtaining services from the IDCs.

The data collected on employment generated by IDCs' beneficiary Small-Scale businesses before and after receiving services (Tables 2-5) were used to test hypothesis 1

The data adapted from generation of employment--i.e. percentage change in employment after receiving services-- were used to test hypothesis 2 .

In selecting the IDCs, a sampling frame was obtained by listing all the IDCs in Nigeria. The frame was divided into geographic locations and sizes of the centres. The geographic locations were grouped into four basic zones-North Western / Central, North Eastern, South Eastern and South Western zones. The selection included the three biggest centres (these were designated as $\mathrm{X}_{1}, \mathrm{X}_{2}, \mathrm{X}_{3}$, and $\mathrm{X}_{4}$ ), and nine of the smaller centres (These were designated as $\mathrm{Y}_{1}, \mathrm{Y}_{2}, \mathrm{Y}_{3}, \mathrm{Y}_{4}, \mathrm{Z}_{1}, \mathrm{Z}_{2}, \mathrm{Z}_{3}$ and $\mathrm{Z}_{4}$ ) in Nigeria. The smaller IDCs were selected by judgmental sampling method.

Twenty five small -scale business beneficiaries were selected from each IDC using convenience/judgmental method. The sampled beneficiaries were selected from beneficiaries that IDCs staff adjudged to have adequate business transactions records and those that could be located by the IDCs' staff.

Student t-test and ANOVA were used to test hypotheses one and two respectively.

\section{Results and Discussion}

The summary results of the findings of the study are presented in Table 1(See details in Tables 2-5).The beneficiary small-scale businesses of the IDCs in the North Central/North Western zone had an increase of 4.3\% in employment generated after receiving IDCs' services .The beneficiaries of IDCX $_{1}$ in the zone had an increase of $3 \%$. The beneficiaries of the IDCY ${ }_{1}$ had an increase of $5.2 \%$, while the beneficiaries of $\mathrm{IDCZ}_{1}$ had an increase of $5 \%$.

The beneficiary small-scale businesses of the IDCs in the North Eastern zone had an increase of $9.7 \%$ in employment generated after receiving IDCs' services. The beneficiaries of IDCX $_{2}$ in the zone had an increase of $9.6 \%$. The beneficiaries of $\mathrm{IDCY}_{2}$ in the zone had an increase of $7.4 \%$, while the beneficiaries of $\mathrm{IDCZ}_{2}$ had an increase of $12.2 \%$.

The beneficiary small-scale businesses of the IDCs in the South Eastern zone had an increase of 3.3\% in employment generated after receiving IDCs' services. The beneficiaries of IDCX $_{3}$ in the zone had a decrease of 
$2.5 \%$. The beneficiaries of $\mathrm{IDCY}_{3}$ had an increase of $6.1 \%$, while beneficiaries of $\mathrm{IDCZ}_{3}$ had an increase of $9.6 \%$.

The beneficiary small-scale businesses of the IDCs in the South Eastern zone had an increase of $5.7 \%$ in employment generated after receiving IDCs' services.The beneficiaries of IDCX4 in the zone had an increase of $0.1 \%$. The beneficiaries of $\mathrm{IDCY}_{4}$ in the zone had an increase of $11.1 \%$, while the beneficiaries of $\mathrm{IDCZ}_{4}$ had an increase of $7.3 \%$.

The beneficiary small-scale businesses of all selected IDCs combined had an increase of $5.7 \%$ in employment generated after receiving IDCs' services

Table 6 shows the result of hypothesis 1

At 5\% level there was significant deference between the number of people employed before and after receiving services by beneficiary small -scale businesses of eight (66.7\%) IDCs. For the rest of the IDCs, there was no significant difference between the employment generated before and after receiving services by their beneficiary small-businesses.

At $1 \%$ level, there was significant difference between the number of people employed before and after receiving services by beneficiary small - scale businesses of four(33.33\%\} IDCs For the other eight IDCs there was no significant difference between the employment generated before and after receiving services by beneficiary small -scale businesses at $1 \%$ level.

Table 7 shows the results of hypothesis 2 .

At $1 \%$ and $5 \%$ levels, there were significant differences among the IDCs regarding changes in employment generation before and after receiving services by beneficiary small-scale businesses

\section{Summary and Conclusion}

In the foregoing an attempt has been made at assessing the impact of Industrial Development Centres (IDCs) on generation of employment of small- scale businesses in Nigeria. Three hundred beneficiary small -businesses of twelve (54.54\%) of the twenty two IDCs in Nigeria were the focus of the study. The study indicated that the services offered by many (66.7\%) of the IDCs led to significant increase in employment generation of large number of beneficiary small- scale businesses at $1 \%$ level.

The study however indicated that the services offered by many (66.7\%) of the IDCs did not lead to significant increase in the employment generation by large number of beneficiary small- scale businesses at $5 \%$ level.

The study also indicated that there were significant differences among the IDCs regarding changes in employment generated by their beneficiary small-scale businesses after receiving services.

Based on the above findings, it is concluded that at $1 \%$ level, the services offered by many of the IDCs had positive impact at $1 \%$ level, but at $5 \%$ level had no positive impact on small-scale businesses regarding employment generated.

\section{References}

Akhouri, M.M.P. (1990). Entrepreneurship and Small Industry Development, Experiences from Asian Region.. A paper delivered at a Workshop organized by the Commonwealth Secretariat in kingston, Jamaica, $26^{\mathrm{th}}-30^{\text {th }}$ March

Aluko, S.A. et al (eds.) (1973). Small-Scale Industries: Mid-Western State, Kwara State: The Industrial Unit, University Ife, Ife, Nigeria

Anderson , D, (1982). Small Industry in Developing Countries: A Discussion of Issues. World Development Volume 10 and 11, pp.913-948

Bryce, M.D. (1965). Policies and Methods for Industrial Development. New-York: McGraw- Hill

CASSAD. (1992). Improving the Fortunes of Small-Scale Industry in Nigeria. Policy Guidelines, Monograph Series 3, Centre for African Studies and Development, Ibadan, Nigeria and and Fredrich-Ebert Foundation of Germany

Chibundu,E.E. (1987). Small-Scale Industries and National Development: Experience from other Nations Proceedings of the National Conference on Small- Scale Industries and Development of Nigeria, NISSER, Ibadan.

Federal Ministry of Finance. (1997). Approved Budget, Vols.1 and 11, Revenue and Recurrent, (1997) Fiscal Year

Isaac Oluwajoba Abereijo and Abimbola Oluwagbenga Fayomi. (2009).'Innovative Approach to SME Financing in Nigeria: A Review of Small and Medium Industries Equity Investment Scheme (SMIEIS) J.Soc.Sci., 11(3):219-227 (2005)

Kilby, P. (ed.) (1971). Entrepreneurship and Economic Development, New-York. Thjoe Fre Press 
Odetola, T.O. (2000). Ministerial Supervision and Management of Resources in Industrial Development Centres - A paper presented at a Seminar organized by Federal Ministry of Industries , Abuja

Omohezuaun and Inegbenebor. (2009). 'Capacity of SMEs in Nigeria to access Institutional Equity Finance'.Research Journal of Business Management2(1): 1-5,2009 ISSN 1819-1932.http://www scialert.net/qredirect.php?doi=rjb.2009.1.5\&linked=pdf.

Schatz, S.P. (1963). 'Economic Environment and private Enterprise in West Africa' The Economic Bulletin (Ghana). Volume 7, No. 4, December

Schmitz, H.C. (1982). 'Growth and Constraints on Small Manufacturing in Developing Countries : A Critical Review. 'World Development, Volume 10, No.6 pp. 429-450

Staley and Morse, (1982), Modern Small-Scale Industry for Developing Countries. New York, McGraw Hill Sutcliffe, R.B. (1971). Industry and underdevelopment, London, Addison -Wesley

Ugwushi Bellema Ihua (2009). 'SMEs Key Failure-factors: A Comparison between the United Kingdom and Nigeria'” J Soc Sci, 18(3): 199-207 (2009).http://www.krepublishers

Table 1. Summary of Employment generated before and after receiving IDCs' services by 25 selected beneficiaries of each IDC

\begin{tabular}{|c|c|c|c|}
\hline Zones/IDCs & \multicolumn{3}{|c|}{ Number/Percentage change in employment generated } \\
\hline $\begin{array}{ll}\text { North } & \text { Central/North } \\
\text { Western } & \end{array}$ & $\begin{array}{ll}\begin{array}{l}\text { Before } \\
\text { services }\end{array} & \text { receiving } \\
\end{array}$ & After receiving services & $\%$ change in employment \\
\hline $\mathrm{X}_{1}$ & 263 & 271 & 3.0 \\
\hline $\mathrm{Y}_{1}$ & 174 & 183 & 5.2 \\
\hline $\mathrm{Z}_{1}$ & 220 & 231 & 5.0 \\
\hline Sub-total & 657 & 685 & 4.3 \\
\hline \multicolumn{4}{|l|}{ North Eastern } \\
\hline $\mathrm{X}_{2}$ & 198 & 217 & 9.6 \\
\hline $\mathrm{Y}_{2}$ & 202 & 217 & 7.4 \\
\hline $\mathrm{Z}_{2}$ & 196 & 220 & 12.2 \\
\hline Sub-total & 596 & 654 & 9.7 \\
\hline \multicolumn{4}{|l|}{ South Eastern } \\
\hline $\mathrm{Y}_{3}$ & 281 & 274 & -2.5 \\
\hline $\mathrm{Y}_{3}$ & 197 & 209 & 6.1 \\
\hline $\mathrm{Z}_{3}$ & 167 & 183 & 9.6 \\
\hline Sub-total & 645 & 666 & 3.3 \\
\hline \multicolumn{4}{|l|}{ South western } \\
\hline $\mathrm{X}_{4}$ & 267 & 269 & 0.7 \\
\hline $\mathrm{Y}_{4}$ & 190 & 211 & 11.1 \\
\hline $\mathrm{Z}_{4}$ & 179 & 192 & 7.3 \\
\hline Sub-total & 636 & & 5.1 \\
\hline Grand T0tal & 2534 & 2,677 & 5.6 \\
\hline
\end{tabular}

Source: Researcher's Survey 
Table 2. Number of staff employed by beneficiary small-scale businesses of selected IDCs in North/Western zone

\begin{tabular}{|c|c|c|c|c|c|c|}
\hline \multirow[b]{3}{*}{$\mathrm{S} / \mathrm{NO}$} & \multicolumn{6}{|c|}{ IDCs/Number of employees employed bybeneficiary small-scale businesses } \\
\hline & \multicolumn{2}{|r|}{$\mathrm{X}_{1}$} & \multicolumn{2}{|c|}{$\mathrm{Y}_{1}$} & \multicolumn{2}{|r|}{$\mathrm{Z}_{1}$} \\
\hline & $\begin{array}{l}\text { Employees } \\
\text { before services }\end{array}$ & $\begin{array}{l}\text { Employees } \\
\text { after services }\end{array}$ & $\begin{array}{l}\text { Employees } \\
\text { before services }\end{array}$ & $\begin{array}{l}\text { Employees } \\
\text { after services }\end{array}$ & $\begin{array}{l}\text { Employees } \\
\text { before services }\end{array}$ & $\begin{array}{l}\text { Employees } \\
\text { after services }\end{array}$ \\
\hline 1 & 08 & 09 & 10 & 10 & 06 & 06 \\
\hline 2 & 08 & 10 & 08 & 08 & 07 & 08 \\
\hline 3 & 05 & 06 & 09 & 08 & 07 & 09 \\
\hline 4 & 08 & 08 & 07 & 08 & 07 & 08 \\
\hline 5 & 09 & 09 & 08 & 08 & 09 & 11 \\
\hline 6 & 06 & 06 & 08 & 07 & 08 & 08 \\
\hline 7 & 18 & 20 & 08 & 08 & 06 & 07 \\
\hline 8 & 14 & 14 & 06 & 06 & 05 & 06 \\
\hline 9 & 12 & 08 & 08 & 07 & 09 & 08 \\
\hline 10 & 16 & 18 & 07 & 08 & 12 & 12 \\
\hline 11 & 07 & 07 & 12 & 14 & 07 & 08 \\
\hline 12 & 07 & 09 & 07 & 08 & 08 & 10 \\
\hline 13 & 09 & 07 & 05 & 05 & 07 & 07 \\
\hline 14 & 20 & 25 & 05 & 06 & 08 & 07 \\
\hline 15 & 07 & 07 & 07 & 06 & 06 & 06 \\
\hline 16 & 09 & 08 & 05 & 07 & 10 & 10 \\
\hline 17 & 11 & 11 & 05 & 05 & 11 & 12 \\
\hline 18 & 08 & 09 & 12 & 13 & 08 & 08 \\
\hline 19 & 07 & 10 & 07 & 07 & 09 & 08 \\
\hline 20 & 10 & 14 & 05 & 06 & 07 & 07 \\
\hline 21 & 08 & 09 & 08 & 07 & 13 & 13 \\
\hline 22 & 06 & 08 & 06 & 06 & 08 & 08 \\
\hline 23 & 15 & 09 & 07 & 07 & 07 & 08 \\
\hline 24 & 09 & 06 & 07 & 05 & 09 & 10 \\
\hline 25 & 13 & 14 & 08 & 09 & 12 & 13 \\
\hline Total & 263 & 271 & 174 & 183 & 220 & 231 \\
\hline
\end{tabular}

Source : Researcher's Survey 
Table 3. Number employees employed before and after receiving services by selected Beneficiary small-scale businesses of IDCs in North Eastern zone

\begin{tabular}{|c|c|c|c|c|c|c|}
\hline \multirow[b]{3}{*}{$\mathrm{S} / \mathrm{NO}$} & \multicolumn{6}{|c|}{ IDCs/Number of employees employed by beneficiary small-scale businesses } \\
\hline & \multicolumn{2}{|c|}{$\mathrm{X}_{2}$} & \multicolumn{2}{|c|}{$\mathrm{Y}_{2}$} & \multicolumn{2}{|c|}{$\mathrm{Z}_{2}$} \\
\hline & $\begin{array}{l}\text { Before } \\
\text { services }\end{array}$ & $\begin{array}{l}\text { After } \\
\text { services }\end{array}$ & $\begin{array}{l}\text { Before } \\
\text { services }\end{array}$ & $\begin{array}{l}\text { After } \\
\text { services }\end{array}$ & $\begin{array}{l}\text { Before } \\
\text { services }\end{array}$ & $\begin{array}{l}\text { After } \\
\text { services }\end{array}$ \\
\hline 1 & 08 & 09 & 10 & 10 & 06 & 06 \\
\hline 2 & 08 & 10 & 08 & 08 & 07 & 08 \\
\hline 3 & 05 & 06 & 09 & 08 & 07 & 09 \\
\hline 4 & 08 & 08 & 07 & 08 & 07 & 08 \\
\hline 5 & 09 & 09 & 08 & 08 & 09 & 11 \\
\hline 6 & 06 & 07 & 07 & 09 & 97 & 08 \\
\hline 7 & 06 & 07 & 08 & 08 & 09 & 10 \\
\hline 8 & 12 & 12 & 09 & 09 & 06 & 06 \\
\hline 9 & 07 & 07 & 08 & 09 & 09 & 12 \\
\hline 10 & 09 & 09 & 08 & 09 & 08 & 10 \\
\hline 11 & 08 & 08 & 06 & 07 & 07 & 07 \\
\hline 12 & 06 & 06 & 07 & 08 & 07 & 09 \\
\hline 13 & 07 & 08 & 07 & 07 & 10 & 13 \\
\hline 14 & 09 & 10 & 09 & 09 & 06 & 06 \\
\hline 15 & 06 & 06 & 09 & 06 & 09 & 08 \\
\hline 16 & 06 & 07 & 06 & 09 & 06 & 06 \\
\hline 17 & 05 & 05 & 08 & 10 & 08 & 10 \\
\hline 18 & 09 & 10 & 07 & 08 & 09 & 09 \\
\hline 19 & 09 & 10 & 07 & 08 & 08 & 08 \\
\hline 20 & 07 & 07 & 06 & 07 & 09 & 08 \\
\hline 21 & 05 & 06 & 12 & 13 & 09 & 09 \\
\hline 22 & 07 & 08 & 09 & 09 & 10 & 14 \\
\hline 23 & 12 & 14 & 10 & 11 & 06 & 09 \\
\hline 24 & 10 & 10 & 09 & 11 & 08 & 08 \\
\hline 25 & 14 & 18 & 08 & 08 & 09 & 08 \\
\hline Total & 198 & 217 & 202 & 217 & 196 & 220 \\
\hline
\end{tabular}

Source: Reasearcher' Survey 
Table 4. Number employees employed before and after receiving services by selected beneficiary small-scale businesses of IDCs in South Eastern zone

\begin{tabular}{|c|c|c|c|c|c|c|}
\hline \multirow[t]{3}{*}{ S/No } & \multicolumn{6}{|c|}{ IDCs/Number of employees employed by beneficiary small-scale businesses } \\
\hline & \multicolumn{2}{|c|}{$\mathrm{X}_{3}$} & \multicolumn{2}{|c|}{$\mathrm{Y}_{3}$} & \multicolumn{2}{|c|}{$\mathrm{Z}_{3}$} \\
\hline & $\begin{array}{l}\text { Before } \\
\text { services }\end{array}$ & $\begin{array}{l}\text { After } \\
\text { services }\end{array}$ & $\begin{array}{l}\text { Before } \\
\text { services }\end{array}$ & $\begin{array}{l}\text { After } \\
\text { services }\end{array}$ & $\begin{array}{l}\text { Before } \\
\text { services }\end{array}$ & $\begin{array}{l}\text { After } \\
\text { services }\end{array}$ \\
\hline 1 & 17 & 17 & 07 & 07 & 08 & 08 \\
\hline 2 & 08 & 07 & 06 & 07 & 07 & 08 \\
\hline 3 & 09 & 09 & 07 & 07 & 14 & 14 \\
\hline 4 & 14 & 15 & 04 & 06 & 06 & 07 \\
\hline 5 & 14 & 14 & 07 & 06 & 05 & 04 \\
\hline 6 & 09 & 08 & 09 & 10 & 07 & 08 \\
\hline 7 & 07 & 05 & 07 & 08 & 13 & 14 \\
\hline 8 & 10 & 12 & 08 & 08 & 06 & 06 \\
\hline 9 & 12 & 12 & 07 & 05 & 08 & 09 \\
\hline 10 & 14 & 13 & 04 & 06 & 06 & 07 \\
\hline 11 & 07 & 06 & 04 & 06 & 08 & 09 \\
\hline 12 & 06 & 06 & 09 & 09 & 07 & 07 \\
\hline 13 & 18 & 14 & 05 & 08 & 08 & 05 \\
\hline 14 & 15 & 16 & 09 & 09 & 06 & 06 \\
\hline 15 & 07 & 07 & 07 & 08 & 12 & 14 \\
\hline 16 & 09 & 09 & 07 & 07 & 06 & 07 \\
\hline 17 & 13 & 13 & 08 & 08 & 14 & 14 \\
\hline 18 & 14 & 15 & 07 & 08 & 06 & 06 \\
\hline 19 & 14 & 13 & 08 & 07 & 05 & 05 \\
\hline 20 & 06 & 06 & 07 & 08 & 06 & 06 \\
\hline 21 & 09 & 08 & 04 & 07 & 10 & 11 \\
\hline 22 & 10 & 10 & 06 & 06 & 07 & 08 \\
\hline 23 & 11 & 10 & 08 & 11 & 12 & 12 \\
\hline 24 & 16 & 15 & 05 & 05 & 05 & 08 \\
\hline 25 & 12 & 14 & 07 & 08 & 08 & 09 \\
\hline Total & 274 & 167 & 183 & 197 & 209 & 220 \\
\hline
\end{tabular}

Source: Researcher's Survey 
Table 5. Number employees employed before and after receiving services by selected beneficiary small-scale businesses of IDCs in South Western zone

\begin{tabular}{|c|c|c|c|c|c|c|}
\hline \multirow[t]{3}{*}{$\mathrm{S} / \mathrm{No}$} & \multicolumn{6}{|c|}{ IDCs/Number of employees employed by beneficiary small-scale businesses } \\
\hline & \multicolumn{2}{|c|}{$\mathrm{X}_{4}$} & \multicolumn{2}{|c|}{$\mathrm{Y}_{4}$} & \multicolumn{2}{|c|}{$\mathrm{Z}_{4}$} \\
\hline & $\begin{array}{l}\text { Before } \\
\text { services }\end{array}$ & $\begin{array}{l}\text { After } \\
\text { services }\end{array}$ & $\begin{array}{l}\text { Before } \\
\text { services }\end{array}$ & $\begin{array}{l}\text { After } \\
\text { services }\end{array}$ & $\begin{array}{l}\text { Before } \\
\text { services }\end{array}$ & $\begin{array}{l}\text { After } \\
\text { services }\end{array}$ \\
\hline 1 & 12 & 14 & 08 & 08 & 06 & 07 \\
\hline 2 & 09 & 09 & 05 & 05 & 08 & 08 \\
\hline 3 & 13 & 14 & 08 & 09 & 08 & 08 \\
\hline 4 & 16 & 18 & 10 & 12 & 05 & 06 \\
\hline 5 & 08 & 09 & 07 & 09 & 08 & 08 \\
\hline 6 & 06 & 06 & 05 & 05 & 09 & 08 \\
\hline 7 & 09 & 09 & 08 & 09 & 06 & 07 \\
\hline 8 & 08 & 08 & 06 & 07 & 06 & 07 \\
\hline 9 & 08 & 07 & 07 & 06 & 08 & 10 \\
\hline 10 & 17 & 14 & 09 & 10 & 07 & 09 \\
\hline 11 & 04 & 04 & 12 & 14 & 08 & 08 \\
\hline 12 & 15 & 13 & 10 & 10 & 06 & 05 \\
\hline 13 & 17 & 17 & 06 & 07 & 06 & 06 \\
\hline 14 & 07 & 06 & 08 & 08 & 07 & 08 \\
\hline 15 & 08 & 07 & 09 & O9 & 09 & 09 \\
\hline 16 & 11 & 12 & 08 & 08 & 09 & 11 \\
\hline 17 & 09 & 09 & 08 & 09 & 08 & 12 \\
\hline 18 & 10 & 10 & 07 & 07 & 08 & 07 \\
\hline 19 & 15 & 14 & 06 & 07 & 07 & 08 \\
\hline 20 & 08 & 08 & 07 & 07 & 06 & 07 \\
\hline 21 & 07 & 09 & 05 & 05 & 07 & 07 \\
\hline 22 & 07 & 09 & 05 & 05 & 07 & 07 \\
\hline 23 & 14 & 15 & 08 & 09 & 05 & 05 \\
\hline 24 & 13 & 15 & 06 & 09 & 09 & 08 \\
\hline 25 & 11 & 11 & 07 & 10 & 05 & 05 \\
\hline Total & 267 & 267 & 190 & 211 & 179 & 192 \\
\hline
\end{tabular}

Source:Researcher's Survey 
Table 6. Summary of results of the hypothesis in respect of changes of employment generated by the beneficiary small-scale businesses before and after receiving services from the IDCs

\begin{tabular}{|c|c|c|c|c|c|c|}
\hline \multirow[t]{3}{*}{ IDCs } & \multirow[t]{3}{*}{ d } & \multirow[t]{3}{*}{$\mathrm{S}_{\mathrm{d}}$} & \multirow[t]{3}{*}{$\operatorname{Ese}(\bar{d})$} & \multirow[t]{3}{*}{ Statistics Test } & \multicolumn{2}{|c|}{ T-Table } \\
\hline & & & & & \multicolumn{2}{|c|}{ Levels } \\
\hline & & & & & $1 \%$ & $5 \%$ \\
\hline $\mathrm{X}_{1}$ & 0.40 & 2.42 & 0.48 & 0.92 & 2.787 & 2.060 \\
\hline $\mathrm{Y}_{1}$ & 0.36 & 1.08 & 0.22 & 1.64 & Ditto & ditto \\
\hline $\mathrm{Z}_{1}$ & 0.44 & .0 .87 & 0.17 & 2.59 & Ditto & ditto \\
\hline $\mathrm{X}_{2}$ & 0.76 & 0.93 & 0.19 & 4.00 & Ditto & ditto \\
\hline $\mathrm{Y}_{2}$ & 0.60 & 1.17 & 0.23 & 2.61 & Ditto & ditto \\
\hline $\mathrm{Z}_{2}$ & 0.96 & 1.40 & 0.28 & 3.43 & Ditto & ditto \\
\hline $\mathrm{X}_{3}$ & 0.28 & 1.15 & 0.23 & -1.22 & Ditto & ditto \\
\hline $\mathrm{Y}_{3}$ & 0.64 & 1.34 & 0.27 & 2.67 & Ditto & ditto \\
\hline$Z_{3}$ & 0.48 & 0.65 & 0.13 & 3.69 & Ditto & ditto \\
\hline $\mathrm{X}_{4}$ & 0.12 & 1.27 & 0.25 & 0.47 & Ditto & ditto \\
\hline $\mathrm{Y}_{4}$ & 0.84 & 1.03 & 0.21 & 4.00 & Ditto & ditto \\
\hline $\mathrm{Z}_{4}$ & 0.52 & 1.16 & 0.23 & 2.26 & Ditto & ditto \\
\hline
\end{tabular}

Table 7. Results of Analysis of Variance in respect of percentage change in employment among beneficiary small-scale businesses of selected IDCs.

\begin{tabular}{|l|l|l|l|l|}
\hline Sources of variation & Sum of squares & Degree of freedom & Mean square & F Ratio \\
\hline Between groups & $32,597.72$ & 11 & $2,963.43$ & 22.34 \\
\hline Within group & $38,208.86$ & 288 & 132.67 & \\
\hline Total & $70,806.58$ & 299 & & \\
\hline
\end{tabular}

Notes: The table at $1 \%$ significant level $=2.34$. The table value at $5 \%$ significant level $=1.83$ 